\title{
Seismic risk assessment of architectural heritages in Gyeongju considering local site effects
}

\author{
H.-J. Park ${ }^{1}$, D.-S. Kim ${ }^{1}$, and D.-M. Kim ${ }^{2}$ \\ ${ }^{1}$ Department of Civil and Environmental Engineering, Korea Advanced Institute of Science and Technology (KAIST), \\ 291 Daehak-ro, Yuseong-gu, Daejeon, Korea \\ ${ }^{2}$ Research Division of Architectural Heritage, National Research Institute of Cultural Heritage, Korea (NRICH), \\ 132 Munji-ro, Yuseong-gu, Daejeon, Korea
}

Correspondence to: D.-S. Kim (dskim@kaist.ac.kr)

Received: 3 January 2012 - Published in Nat. Hazards Earth Syst. Sci. Discuss.: -

Revised: 9 October 2012 - Accepted: 1 December 2012 - Published: 8 February 2013

\begin{abstract}
A seismic risk assessment is conducted for cultural heritage sites in Gyeongju, the capital of Korea's ancient Silla Kingdom. Gyeongju, home to UNESCO World Heritage sites, contains remarkable artifacts of Korean Buddhist art. An extensive geotechnical survey including a series of in situ tests is presented, providing pertinent soil profiles for site response analyses on thirty cultural heritage sites. After the shear wave velocity profiles and dynamic material properties were obtained, site response analyses were carried out at each historical site and the amplification characteristics, site period, and response spectrum of the site were determined for the earthquake levels of $2400 \mathrm{yr}$ and $1000 \mathrm{yr}$ return periods based on the Korean seismic hazard map. Response spectrum and corresponding site coefficients obtained from site response analyses considering geologic conditions differ significantly from the current Korean seismic code. This study confirms the importance of site-specific ground response analyses considering local geological conditions. Results are given in the form of the spatial distribution of bedrock depth, site period, and site amplification coefficients, which are particularly valuable in the context of a seismic vulnerability study. This study presents the potential amplification of hazard maps and provides primary data on the seismic risk assessment of each cultural heritage.
\end{abstract}

\section{Introduction}

Gyeongju, the capital of the ancient Silla Kingdom ( $57 \mathrm{BC} \sim 935 \mathrm{AD})$, is considered the most important historic city in Korea and contains remarkable artifacts of Korean
Buddhist art. Gyeongju is located in a relatively higher earthquake prone region nearby the Yangsan fault line and has historical records of frequent seismic damage. In particular, the region's valuable architectural heritages are exposed to seismic danger. A seismic risk assessment is therefore required to prevent damage to the area's architectural heritages.

It has been well documented that local site effects may substantially affect amplification of ground motion with the dominant site period range, because earthquake motions at the bedrock can be drastically modified in amplitude, frequency content, and duration during the propagation of seismic waves within soil (Aki, 1993; Kim et al., 2002; Pitilakis, 2004; Sun et al., 2005; Chavez-Garcia, 2007). In the Korean seismic design code (MOCT, 1997), local site effects are considered according to a site classification system and corresponding site coefficients, which are similar to the 1994 and 1997 NEHRP Provisions (BSSC, 1994, 1997), despite substantial differences in local geological conditions. Kim and Yoon (2005) and Lee et al. (2012) showed significant deviations in response spectra between soil response analyses and code-defined values.

Rock-outcrop motions defined in the Korean seismic design code correspond to seismic hazard maps developed for various return periods based on historical earthquake events based on the relation of ground motions to earthquake intensities. Because most of the historical events were not experienced at rock outcrops but rather at the ground surface of the soil sites and the effects of site amplification were already included in the historical earthquake intensities, the rock-outcrop motion in the hazard map is potentially overestimated. In order to assess the extent of potential 


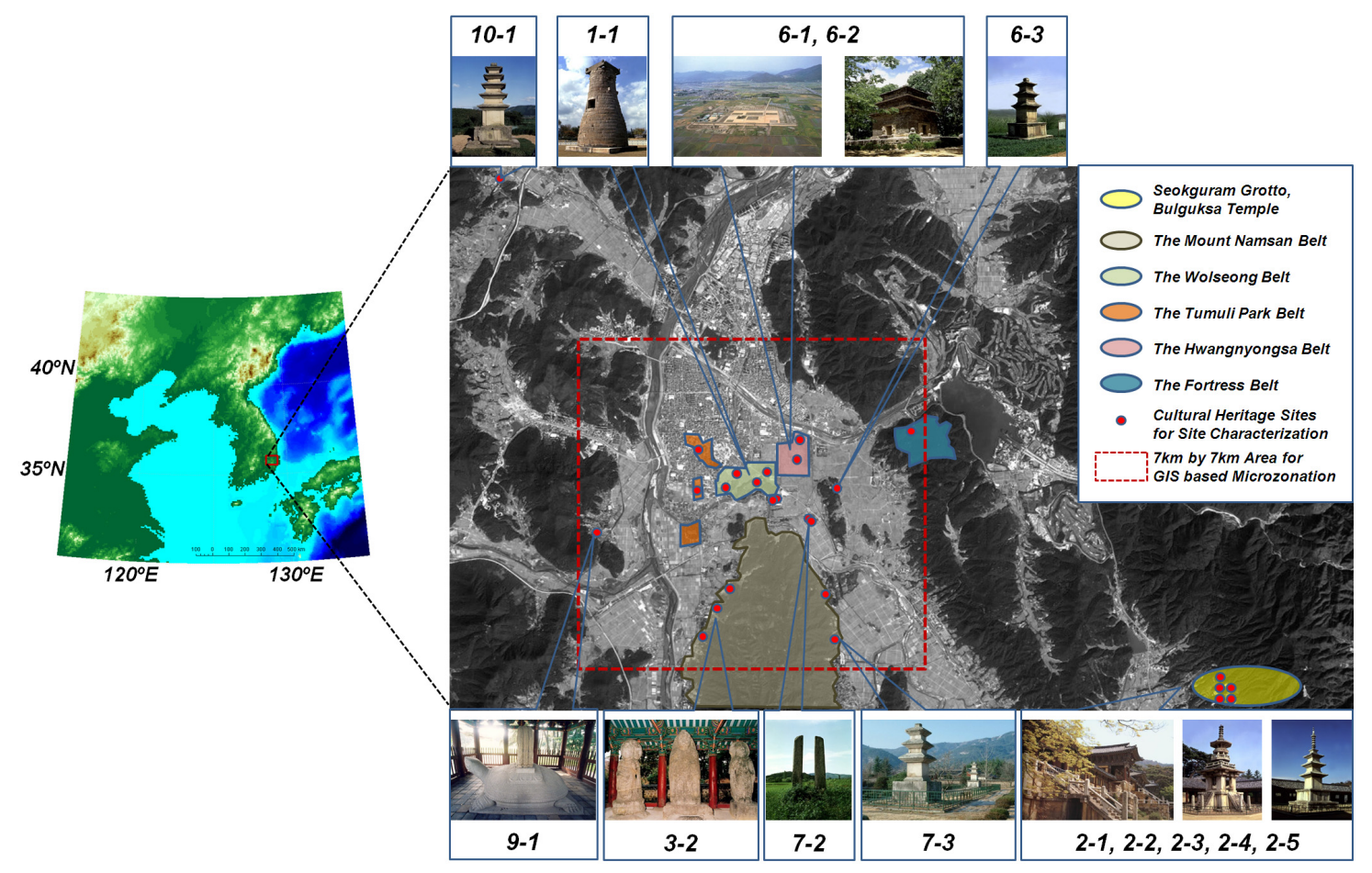

Fig. 1. The satellite picture of Gyeongju historical areas, the location and foreground of typical cultural heritages.

overestimation in the hazard map, it is essential to evaluate the range of site amplification at various historical sites using a ground response analysis and interpret the spatial geotechnical information, such as depth to bedrock, site period, and amplification characteristics, using a geographic information system (GIS).

In this study, site response analyses were performed at historical sites in Gyeongju to assess seismic risk. Thirty historical sites of cultural heritages were selected considering importance and geographical distributions, and the representative shear wave velocity (Vs) profiles were determined by surface wave tests. One-dimensional site response analyses were carried out at each historical site and the amplification characteristics, site period, and response spectrum of the site were determined. Amplification coefficients and the corresponding response spectra were compared with the coded values and the importance of a site-specific analysis for risk assessments was demonstrated. Sixty pre-existing soil datasets were gathered in the central area around a $7 \mathrm{~km}$ by $7 \mathrm{~km}$ area encompassing Gyeongju and ground response analyses were additionally performed. Necessary information for seismic risk assessment such as bedrock depth, site period, peak ground acceleration, and site amplification coefficients was spatially interpreted for the scenario earthquakes and the potential overestimation of rock-outcrop motion in a hazard map based on historical records was assessed. Seismic microzonation becomes particular valuable in the case of assessing the seismic vulnerability of historical monuments and cultural heritages due to the case-dependent nature of their seismic performance.

\section{Selection of test sites around Gyeongju historic areas}

Among the many cultural heritages in Gyeongju, cultural heritage sites with historical earthquake records and other national architectural treasure sites were selected for site investigation and ground response analysis. The UNESCO World Heritage sites selected for this study include "Seokguram Grotto and Bulguksa Temple", "Gyeongju Historic Areas", and "Yangdong Village".

The Gyeongju Historic Areas host outstanding examples of Korean Buddhist art including sculptures, reliefs, pagodas, and the remains of temples and palaces from the period of the seventh to the tenth centuries, marking the culmination of this form of artistic expression. There are five major belts that make up the Gyeongju Historic Areas: the Mount Namsan Belt, the Wolseong Belt, the Tumuli Park Belt, the Hwangnyongsa Belt, and the Fortress Belt, as shown in Fig. 1.

The historical data of earthquakes in the Gyeongju area are tabulated in Table 1 (NRICH, 2009). Notably, the cultural heritage sites that experienced damage to structures due to earthquake events include the "three storied stone pagoda at Bulguksa Temple (Site No. 2-2)," "Hwangnyongsa Temple site (Site No. 6-1)," and "Mangdeoksa Temple site (Sites No. 7-1 and 7-2)". Note that mountains and rock outcrops have relatively lower possibilities of local site amplification 
Table 1. Historical records of seismic damage in Gyeongju.

\begin{tabular}{|c|c|c|c|c|c|c|c|}
\hline Month, Year & Historical Records on the Earthquake for Gyeongju & $\begin{array}{l}\text { Inscribed } \\
\text { Korean } \\
\text { Memory }\end{array}$ & $\begin{array}{l}\text { Classification } \\
\text { of Memory in Korea }\end{array}$ & $\begin{array}{l}\text { Surface } \\
\text { Geology } \\
\text { (NRICH, } \\
2009 \text { ) }\end{array}$ & $\begin{array}{l}\text { Seismic } \\
\text { Intensity } \\
\text { (NRICH, } \\
\text { 2009) }\end{array}$ & $\begin{array}{l}\text { Magnitude } \\
\text { by } \\
\text { Inference } \\
\text { (NRICH, } \\
2009 \text { ) }\end{array}$ & $\begin{array}{l}\text { Potential Amplification } \\
\text { (in this study) }\end{array}$ \\
\hline Dec. $27 \mathrm{AD}$ & The ground shook and residences collapsed. & \multirow{12}{*}{$\begin{array}{l}\text { Samguksagi } \\
\text { (History of } \\
\text { the three kingdoms) }\end{array}$} & \multirow{12}{*}{$\begin{array}{l}\text { Treasures No. } 525 \text {, } \\
722,723\end{array}$} & & $\sim 7-8$ & $\sim 5.0-6.0$ & $\begin{array}{l}\sim 1.46-1.53 \text { (Mean value of } \\
\text { Gyeongju area) }\end{array}$ \\
\hline Jul. $89 \mathrm{AD}$ & $\begin{array}{l}\text { The ground shook and cracked. Many people died } \\
\text { as residential homes collapsed. }\end{array}$ & & & & $\sim 8-9$ & $\sim 5.5-6.5$ & $\begin{array}{l}\sim 1.46-1.53 \text { (Mean value of } \\
\text { Gyeongju area) }\end{array}$ \\
\hline Dec. $100 \mathrm{AD}$ & $\begin{array}{l}\text { Residences collapsed and some people died after } \\
\text { ground shaking. }\end{array}$ & & & & $\sim 8-9$ & $\sim 5.0-6.5$ & $\begin{array}{l}\sim 1.46-1.53 \text { (Mean value of } \\
\text { Gyeongju area) }\end{array}$ \\
\hline Oct. $304 \mathrm{AD}$ & $\begin{array}{l}\text { Residences collapsed and some people died after } \\
\text { ground shaking. }\end{array}$ & & & & $\sim 8-9$ & $\sim 5.0-6.5$ & $\begin{array}{l}\sim 1.46-1.53 \text { (Mean value of } \\
\text { Gyeongju area) }\end{array}$ \\
\hline Nov. $502 \mathrm{AD}$ & $\begin{array}{l}\text { Residences collapsed and some people died after } \\
\text { ground shaking. }\end{array}$ & & & & $\sim 8-9$ & $\sim 5.0-6.5$ & $\begin{array}{l}\sim 1.46-1.53 \text { (Mean value of } \\
\text { Gyeongju area) }\end{array}$ \\
\hline Jun. $510 \mathrm{AD}$ & $\begin{array}{l}\text { Residences collapsed and some people died after } \\
\text { ground shaking. }\end{array}$ & & & & $\sim 8-9$ & $\sim 5.0-6.5$ & $\begin{array}{l}\sim 1.46-1.53 \text { (Mean value of } \\
\text { Gyeongju area) }\end{array}$ \\
\hline Sep. $664 \mathrm{AD}$ & $\begin{array}{l}\text { Residences collapsed after ground shaking. } \\
\text { The southern region was more severely affected. }\end{array}$ & & & & $\sim 7-8$ & $\sim 5.5-6.0$ & $\begin{array}{l}\sim 1.46-1.53 \text { (Mean value of } \\
\text { Gyeongju area) }\end{array}$ \\
\hline $775 \mathrm{AD}$ & The pagoda of Mangdeoksa Temple was shaken. & & & $\begin{array}{l}\text { Holocene, } \\
\text { Younger } \\
\text { Alluvium }\end{array}$ & $\sim 6-7$ & 4.5 & $\begin{array}{l}\sim 1.66-1.81 \text { (Site No. } 7-1 \text {, } \\
7-2 \text { ) }\end{array}$ \\
\hline Jun. $768 \mathrm{AD}$ & $\begin{array}{l}\text { A great star fell at the southern region of } \\
\text { Hwangnyongsa Temple. } \\
\text { An earthquake occurred and sounded like thunder. }\end{array}$ & & & $\begin{array}{l}\text { Holocene, } \\
\text { Younger } \\
\text { Alluvium }\end{array}$ & 6 & 4.5 & $\sim 1.32-1.35$ (Site No. $6-1)$ \\
\hline $779 \mathrm{AD}$ & $\begin{array}{l}\text { The ground of Gyeongju shook. } \\
\text { Residences collapsed and one hundred people died. }\end{array}$ & & & & $\sim 8-9$ & $\sim 6.0-6.5$ & $\begin{array}{l}\sim 1.46-1.53 \text { (Mean value of } \\
\text { Gyeongju area) }\end{array}$ \\
\hline Mar. $798 \mathrm{AD}$ & $\begin{array}{l}\text { The two pagodas of Mangdeoksa Temple bumped } \\
\text { against each other. }\end{array}$ & & & $\begin{array}{l}\text { Holocene, } \\
\text { Younger } \\
\text { Alluvium }\end{array}$ & $\sim 6-7$ & 4.5 & $\begin{array}{l}\sim 1.66-1.81 \text { (Site No. } 7-1 \text {, } \\
7-2)\end{array}$ \\
\hline Jul. $804 \mathrm{AD}$ & $\begin{array}{l}\text { The two pagodas of Mangdeoksa Temple bumped } \\
\text { against each other. }\end{array}$ & & & $\begin{array}{l}\text { Holocene, } \\
\text { Younger } \\
\text { Alluvium }\end{array}$ & $\sim 6-7$ & 4.5 & $\begin{array}{l}\sim 1.66-1.81 \text { (Site No. } 7-1, \\
7-2)\end{array}$ \\
\hline Jun. $1036 \mathrm{AD}$ & $\begin{array}{l}\text { After a major earthquake around Gyeongju, a three } \\
\text { storied stone pagoda at Bulguksa Temple was on the } \\
\text { verge of collapse. }\end{array}$ & \multirow[t]{2}{*}{$\begin{array}{l}\text { Mukseojipyeon } \\
\text { (Piece of ink } \\
\text { on the paper) }\end{array}$} & \multirow[t]{2}{*}{$\begin{array}{l}\text { National Treasures } \\
\text { No. } 126-28\end{array}$} & $\begin{array}{l}\text { Biotite } \\
\text { Granite }\end{array}$ & $\sim 7-8$ & $\sim 5.5-6.5$ & $\sim 1.46-1.74$ (Site No. $2-2$ ) \\
\hline Jul. $1036 \mathrm{AD}$ & $\begin{array}{l}\text { The southern facilities of Bulguksa Temple } \\
\text { collapsed. } \\
\text { The three storied stone pagoda at Bulguksa Temple } \\
\text { on the verge of collapse. }\end{array}$ & & & $\begin{array}{l}\text { Biotite } \\
\text { Granite }\end{array}$ & $\sim 7-8$ & $\sim 5.5-6.5$ & $\sim 1.46-1.74$ (Site No. $2-2$ ) \\
\hline
\end{tabular}

and seismic hazards. Therefore, cultural properties in mountain areas were excluded from this study. In this study, rock outcrops were considered as the reference point for the survey. Four trig points of Mount Namsan (South Mountain), three trig points of the western area, and two trig points of the north-eastern area were used. Thirty cultural heritage sites in Gyeongju were selected for the in situ tests, as listed in Table 2.

In order to evaluate the GIS based seismic risk for the Gyeongju historic areas, a zone of $7 \mathrm{~km}$ by $7 \mathrm{~km}$ (Fig. 1), which includes the historic area and the current downtown area, was selected. Various pre-existing site investigation results in this zone were used as shown in the corresponding map of Fig. 7d (Kim et al., 2002; Sun et al., 2005). Sixty site characterization data, including the results of boring, standard penetration test, seismic tests, and laboratory tests were collected for this study. Figure 1 shows the location of Gyeongju historical areas and some representative cultural heritage sites.

\section{Site characterization using in situ seismic tests}

A harmonic wavelet analysis of wave (HWAW) test, a kind of seismic surface wave test, was performed around the thirty cultural heritage sites in order to measure the Vs profile of the site. In the "Cheomseongdae observatory (Site No. 11)", boring and downhole tests were executed to check the reliability of the HWAW method.

The HWAW test is a non-intrusive test that uses surface waves. It is based on the harmonic wavelet transform, which can be used to evaluate dispersive phases and group velocities of surface waves. Park and Kim (2001) proposed a step by step procedure of the HWAW method. After source generation with sledge hammer, the harmonic wavelet transform decomposes, the signals obtained at receivers 1 and 2 into frequency components in the time domain. This transform determines the energy and phase time-frequency maps, which describe the instantaneous energy and phase of the frequency components with time. The group and phase delays of each frequency component are determined from the instantaneous energy and phase information. The group delay refers to time corresponding to the maximum energy and the phase delay is the time corresponding to a certain fixed phase around the maximum energy time. If the distance between receiver 1 and receiver 2 is known, then the group velocity and the phase velocity at each frequency can be obtained. The HWAW method uses the signal portion of the maximum local signal/noise ratio to evaluate the phase velocity. This can 
Table 2. Cultural heritage sites for in situ test and ground response analysis in Gyeongju.

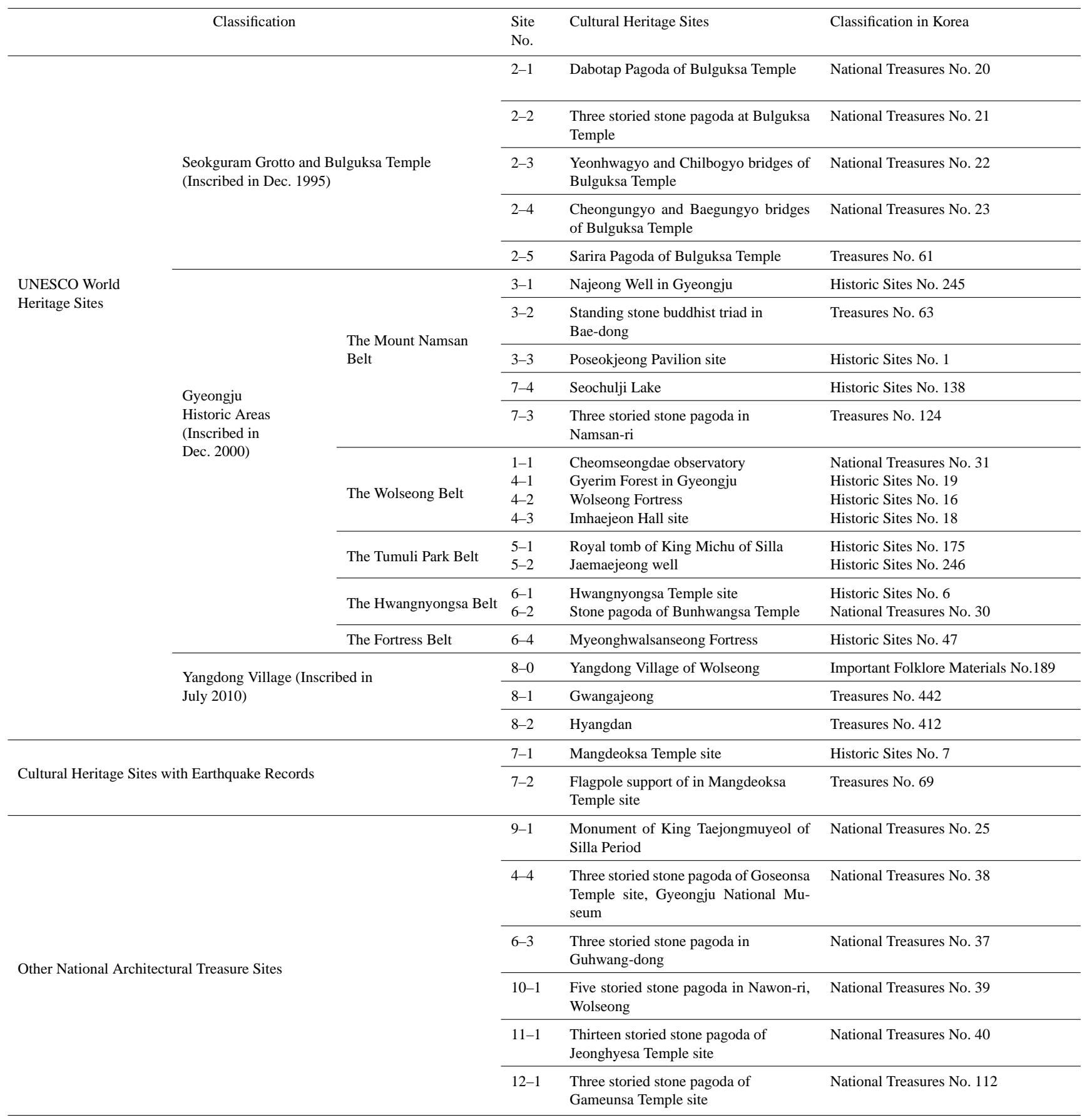

minimize the effects of noise. For the site characterization, the HWAW method generally uses a short receiver spacing setup. The source-receiver spacing $(D)$ is $\sim 6-12 \mathrm{~m}$ and the receiver spacing $(R)$ is $\sim 1-3 \mathrm{~m}$. Because the HWAW method uses a short receiver spacing setup, it can minimize the possibility of error due to lateral non-homogeneity and can be used to determine a more detailed local soil profile as compared to the conventional SASW method (Park and Kim, 2001).
Twenty-eight HWAW tests, fourteen SASW tests, a boring investigation, and a downhole test were conducted in thirty cultural heritage sites of Gyeongju. Figure 2 shows the thirty Vs profiles based on the in situ seismic tests. The site conditions can be characterized into six categories according to the mean shear wave velocity of the upper $30 \mathrm{~m}$ (Vs30), as suggested in the Korean seismic design code. Most of the ground in Gyeongju was found to be $S_{\mathrm{C}}$ (very stiff soil 
of soft rock; $360<\mathrm{Vs} 30 \leq 760$ ), and others as $S_{\mathrm{B}}$ (rock; $760<$ Vs $30 \leq 1500$ ) or $S_{\mathrm{D}}$ (stiff soil; $180<$ Vs $30 \leq 360$ ).

\section{Local site effects}

\subsection{Design rock-outcrop motion}

Even though an earthquake resistant design code for the cultural heritage sites has not yet been proposed in Korea, considering the importance of a ripple effect on the collapse of the architectural heritage sites, the design rockoutcropping acceleration is considered for special structures and/or seismic class I structures at a collapse level earthquake in this study. The design rock-outcropping accelerations at Gyeongju were $0.20 \mathrm{~g}$ for the special structures $(2400 \mathrm{yr}$ return period) and $0.14 \mathrm{~g}$ for seismic class I structures $(1000 \mathrm{yr}$ return period) at a collapse level earthquake based on the Korean seismic hazard map.

\subsection{Dynamic soil properties and input ground motions}

Since ground motion is significantly affected by local site effects, the compositions of the entire soil strata, determined by individual boring and seismic investigations, were separately utilized in the analyses. For the site-specific ground response analyses, thirty sets of in situ test results around cultural heritages and the sixty sets of pre-existing data were used. The sixty pre-existing datasets were composed of fortyfour boring investigations, four crosshole tests, twelve downhole tests, and twenty-six SASW tests.

Input soil properties, such as Vs profile, mass density, and modulus reduction and damping curves, were determined for each layer. The bedrock locations where Vs were higher than $760 \mathrm{~m} \mathrm{~s}^{-1}$ were determined from seismic tests. As shown by the pre-existing site investigation results for Gyeongju, most soil layers were alluvial soils classified as either sand or gravel, such as GP, GM, SP, SW, and SM, in the unified soil classification system (Kim et al., 2002). The normalized shear moduli $\left(G / G_{\max }\right)$ and damping ratios $(D)$ with shear strain for the alluvial and weathered residual soils were determined by resonant column tests with reconstituted specimens considering in situ conditions. Figure 3 shows the representative normalized shear modulus reduction and damping curves of each alluvial and weathered residual soil for the ground response analysis. In the case of gravel and weathered rock, the corresponding $G / G_{\max }$ and damping curves in the literature were used (Schnabel et al., 1972; Seed et al., 1986).

One artificial synthetic earthquake, three strong motion recordings and one weak motion recording were used as input ground motions. The input rock-outcropping accelerations were modified to the levels of collapse level earthquakes. Among the input motions, three strong motion recordings, El Centro, Hachinohe, and Ofunato earthquake motions, which were recorded in strong seismic regions, were included due to the lack of strong motion records of earthquakes in Korea. To reflect the characteristics of regional seismicity, an earthquake acceleration waveform recorded in Gyeongju was also applied to derive site response data.

\subsection{One-dimensional site response analysis}

Site response analyses of Gyeongju were performed by using a one-dimensional equivalent linear scheme of the SHAKE program (Schnabel et al., 1972). This equivalent linear analysis provides relatively reliable results when the strain level caused by an earthquake is lower than one percent, which is a typical range in moderate seismic zones such as Gyeongju (Kim et al., 2002). Through the equivalent linear analysis, more precise natural period value and amplification characteristics considering nonlinearity of soil deposits could be obtained at each site.

Figure 4 summarizes heritage information, in situ test results, and site-specific ground response analysis results for the "Cheomseongdae observatory (Site No. 1-1)". Cheomseongdae, an astronomical observatory, was estimated to have been built in the period of Queen Seondeok ( AD 632647) in the Silla Era. It is highly valued as the oldest astronomical observatory in Asia. The representative shear wave velocity, the mean value of downhole and HWAW test results, was used for the site response analysis of the Cheomseongdae ground.

In the case of Cheomseongdae, the peak ground accelerations were $0.370 \mathrm{~g}$ for the earthquake level of a $2400 \mathrm{yr}$ return period and $0.259 \mathrm{~g}$ for the earthquake level of a $1000 \mathrm{yr}$ return period. Depending on the local site effects, a maximum of 1.85 times site amplification is expected. Notably, the deep alluvial layers, which are common in the Gyeongju area, show high potential for amplification. The site periods of the Cheomseongdae ground are $\sim 0.21-0.23 \mathrm{~s}$.

The cultural heritage information, in situ test results, and site-specific analysis results for thirty heritage sites are summarized in the same manner as in Fig. 4. The site information, the Vs30, peak ground accelerations, site coefficient, and site periods were determined at thirty heritage sites, and are tabulated in Table 3. Site amplification coefficients are listed in the last column of Table 1.

Considering the maximum acceleration amplification between rock-outcrop motion and free surface motion for the thirty cultural heritage sites, the "three storied stone pagoda in Namsan-ri (Site No. 7-3)", the "Cheomseongdae observatory (Site No. 1-1)", and the "flagpole support of in Mangdeoksa Temple site (Site No. 7-2)" were expected to have more than 1.5 times site amplification. On the contrary, "Gwangajeong (Site No. 8-1)" and "Hyangdan (Site No. 8-2)" in Yangdong Village, the "five storied stone pagoda in Nawon-ri (Site No. 10-1), Wolseong", the "standing stone Buddhist triad in Bae-dong (Site No. 3-2)", and the "stone pagoda of Bunhwangsa Temple (Site No. 6-2)" had relatively low site amplification. 
Table 3. The results of site-specific ground response analysis for cultural heritage sites.

\begin{tabular}{|c|c|c|c|c|c|c|c|c|c|c|c|c|c|c|c|c|c|c|}
\hline \multirow[b]{2}{*}{$\begin{array}{l}\text { Site } \\
\text { No. }\end{array}$} & \multirow[b]{2}{*}{$\begin{array}{l}\text { Cultural } \\
\text { Heritage } \\
\text { Sites }\end{array}$} & \multirow[b]{2}{*}{$\begin{array}{l}\text { Latitude } \\
\left({ }^{\circ} \mathrm{N}\right)\end{array}$} & \multirow[b]{2}{*}{$\begin{array}{l}\text { Longitude } \\
\left({ }^{\circ} \mathrm{E}\right)\end{array}$} & \multirow[b]{2}{*}{$\begin{array}{l}\text { Elevation } \\
(\mathrm{m})\end{array}$} & \multirow[b]{2}{*}{$\begin{array}{l}\text { Bed } \\
\text { rock } \\
\text { Depth } \\
\text { (m) }\end{array}$} & \multirow{2}{*}{$\begin{array}{l}\text { Mean } \\
\text { Shear } \\
\text { Wave } \\
\text { Velocity } \\
\text { to } 30 \mathrm{~m} \text {, } \\
\text { Vs30 } \\
\left(\mathrm{m} \mathrm{s}^{-1}\right)\end{array}$} & \multirow{2}{*}{$\begin{array}{l}\text { Site } \\
\text { Class } \\
\text { by } \\
\text { Korean } \\
\text { seismic } \\
\text { design } \\
\text { guide }\end{array}$} & \multicolumn{2}{|c|}{$\begin{array}{l}\text { Average Peak } \\
\text { Ground } \\
\text { Acceleration (g) }\end{array}$} & \multicolumn{2}{|c|}{$\begin{array}{c}\text { Site } \\
\text { Amplification } \\
\text { Coefficient }\end{array}$} & \multicolumn{2}{|c|}{$\begin{array}{l}\text { Short-period } \\
\text { Site } \\
\text { Coefficient, Fa }\end{array}$} & \multicolumn{2}{|c|}{$\begin{array}{l}\text { Long-period } \\
\text { Site } \\
\text { Coefficient, Fv } \\
\end{array}$} & \multicolumn{3}{|c|}{ Site Period (Sec) } \\
\hline & & & & & & & & $\begin{array}{l}\text { Special } \\
\text { CLE } \\
(2400 \\
\text { yr })\end{array}$ & $\begin{array}{l}\text { CLE I } \\
(1000 \\
\mathrm{yr})\end{array}$ & $\begin{array}{l}\text { Special } \\
\text { CLE } \\
(2400 \\
\text { yr })\end{array}$ & $\begin{array}{l}\text { CLE I } \\
(1000 \\
\text { yr })\end{array}$ & $\begin{array}{l}\text { Special } \\
\text { CLE } \\
(2400 \\
\text { yr })\end{array}$ & $\begin{array}{l}\text { CLE I } \\
(1000 \\
\mathrm{yr})\end{array}$ & $\begin{array}{l}\text { Special } \\
\text { CLE } \\
(2400 \\
\text { yr })\end{array}$ & $\begin{array}{l}\text { CLE I } \\
(1000 \\
\text { yr })\end{array}$ & $\begin{array}{l}\text { Special } \\
\text { CLE } \\
(2400 \\
\text { yr })\end{array}$ & $\begin{array}{l}\text { CLE I } \\
(1000 \\
\text { yr })\end{array}$ & $\begin{array}{l}\text { by } \\
\text { Soil } \\
\text { Profile }\end{array}$ \\
\hline $2-1$ & $\begin{array}{l}\text { Dabotap Pagoda of } \\
\text { Bulguksa Temple }\end{array}$ & $35^{\circ} 47^{\prime} 24^{\prime \prime}$ & $129^{\circ} 19^{\prime} 57^{\prime \prime}$ & 249 & 12.7 & 598 & $\mathrm{C}$ & 0.291 & 0.244 & 1.46 & 1.74 & 1.413 & 1.658 & 1.054 & 1.148 & 0.15 & 0.14 & 0.15 \\
\hline $2-2$ & $\begin{array}{l}\text { Three storied stone pagoda } \\
\text { at Bulguksa Temple }\end{array}$ & $35^{\circ} 47^{\prime} 24^{\prime \prime}$ & $129^{\circ} 19^{\prime} 56^{\prime \prime}$ & 249 & 12.7 & 598 & $\mathrm{C}$ & 0.291 & 0.244 & 1.46 & 1.74 & 1.413 & 1.658 & 1.054 & 1.148 & 0.15 & 0.14 & 0.15 \\
\hline $2-3$ & $\begin{array}{l}\text { Yeonhwagyo and } \\
\text { Chilbogyo bridges of } \\
\text { Bulguksa Temple }\end{array}$ & $35^{\circ} 47^{\prime} 23^{\prime \prime}$ & $129^{\circ} 19^{\prime} 56^{\prime \prime}$ & 243 & 13.5 & 505 & $\mathrm{C}$ & 0.267 & 0.187 & 1.34 & 1.34 & 1.532 & 1.514 & 1.174 & 1.131 & 0.26 & 0.23 & 0.18 \\
\hline $2-4$ & $\begin{array}{l}\text { Cheongungyo and } \\
\text { Baegungyo bridges of } \\
\text { Bulguksa Temple }\end{array}$ & $35^{\circ} 47^{\prime} 23^{\prime \prime}$ & $129^{\circ} 19^{\prime} 57^{\prime \prime}$ & 243 & 13.5 & 505 & $\mathrm{C}$ & 0.267 & 0.187 & 1.34 & 1.34 & 1.532 & 1.514 & 1.174 & 1.131 & 0.26 & 0.23 & 0.18 \\
\hline $2-5$ & $\begin{array}{l}\text { Sarira Pagoda of Bulguksa } \\
\text { Temple }\end{array}$ & $35^{\circ} 47^{\prime} 26^{\prime \prime}$ & $129^{\circ} 19^{\prime} 55^{\prime \prime}$ & 251 & 20.0 & 493 & $\mathrm{C}$ & 0.298 & 0.211 & 1.49 & 1.51 & 1.718 & 1.696 & 1.221 & 1.173 & 0.27 & 0.24 & 0.20 \\
\hline $3-1$ & Najeong Well in Gyeongju & $35^{\circ} 48^{\prime} 55^{\prime \prime}$ & $129^{\circ} 12^{\prime} 46^{\prime \prime}$ & 56 & 26.0 & 386 & $\mathrm{C}$ & 0.255 & 0.200 & 1.28 & 1.43 & 1.654 & 1.717 & 1.346 & 1.284 & 0.35 & 0.32 & 0.29 \\
\hline $3-2$ & $\begin{array}{l}\text { Standing stone buddhist } \\
\text { triad in Bae-dong }\end{array}$ & $35^{\circ} 48^{\prime} 5^{\prime \prime}$ & $129^{\circ} 12^{\prime} 40^{\prime \prime}$ & 74 & 14.0 & 603 & $\mathrm{C}$ & 0.260 & 0.184 & 1.30 & 1.31 & 1.291 & 1.260 & 1.037 & 1.032 & 0.12 & 0.13 & 0.14 \\
\hline $3-3$ & Poseokjeong Pavilion site & $35^{\circ} 48^{\prime} 25^{\prime \prime}$ & $129^{\circ} 12^{\prime} 46^{\prime \prime}$ & 53 & 14.0 & 584 & $\mathrm{C}$ & 0.298 & 0.200 & 1.49 & 1.43 & 1.438 & 1.406 & 1.062 & 1.051 & 0.14 & 0.13 & 0.14 \\
\hline $7-4$ & Seochulji Lake & $35^{\circ} 47^{\prime} 45^{\prime \prime}$ & $129^{\circ} 14^{\prime} 32^{\prime \prime}$ & 95 & 31.0 & 382 & $\mathrm{C}$ & 0.274 & 0.205 & 1.37 & 1.46 & 1.668 & 1.678 & 1.253 & 1.203 & 0.31 & 0.28 & 0.31 \\
\hline $7-3$ & $\begin{array}{l}\text { Three storied stone pagoda } \\
\text { in Namsan-ri }\end{array}$ & $35^{\circ} 47^{\prime} 35^{\prime \prime}$ & $129^{\circ} 14^{\prime} 40^{\prime \prime}$ & 75 & 32.0 & 296 & $\mathrm{D}$ & 0.359 & 0.269 & 1.80 & 1.92 & 2.290 & 2.535 & 1.880 & 1.751 & 0.44 & 0.39 & 0.42 \\
\hline $1-1$ & $\begin{array}{l}\text { Cheomseongdae } \\
\text { observatory }\end{array}$ & $35^{\circ} 50^{\prime} 4^{\prime \prime}$ & $129^{\circ} 13^{\prime} 9^{\prime \prime}$ & 47 & 17.7 & 431 & $\mathrm{C}$ & 0.370 & 0.259 & 1.85 & 1.85 & 1.654 & 1.635 & 1.100 & 1.086 & 0.22 & 0.21 & 0.23 \\
\hline $4-1$ & Gyerim Forest in Gyeongju & $35^{\circ} 49^{\prime} 56^{\prime \prime}$ & $129^{\circ} 13^{\prime} 7^{\prime \prime}$ & 45 & 14.0 & 552 & $\mathrm{C}$ & 0.298 & 0.205 & 1.49 & 1.46 & 1.425 & 1.389 & 1.054 & 1.046 & 0.14 & 0.13 & 0.15 \\
\hline $4-2$ & Wolseong Fortress & $35^{\circ} 49^{\prime} 59^{\prime \prime}$ & $129^{\circ} 13^{\prime} 28^{\prime \prime}$ & 60 & 14.0 & 402 & $\mathrm{C}$ & 0.315 & 0.253 & 1.58 & 1.81 & 1.913 & 1.987 & 1.316 & 1.255 & 0.30 & 0.27 & 0.22 \\
\hline $4-3$ & Imhaejeon Hall site & $35^{\circ} 50^{\prime} 3^{\prime \prime}$ & $129^{\circ} 13^{\prime} 36^{\prime \prime}$ & 56 & 18.0 & 470 & $\mathrm{C}$ & 0.379 & 0.261 & 1.90 & 1.86 & 1.714 & 1.676 & 1.103 & 1.087 & 0.18 & 0.17 & 0.20 \\
\hline $5-1$ & $\begin{array}{l}\text { Royal tomb of King Michu } \\
\text { of Silla }\end{array}$ & $35^{\circ} 50^{\prime} 18^{\prime \prime}$ & $129^{\circ} 12^{\prime} 39^{\prime \prime}$ & 41 & 22.0 & 474 & C & 0.366 & 0.264 & 1.83 & 1.89 & 1.733 & 1.706 & 1.130 & 1.111 & 0.21 & 0.19 & 0.22 \\
\hline $5-2$ & Jaemaejeong well & $35^{\circ} 49^{\prime} 43^{\prime \prime}$ & $129^{\circ} 12^{\prime} 47^{\prime \prime}$ & 37 & 22.0 & 480 & $\mathrm{C}$ & 0.337 & 0.235 & 1.69 & 1.68 & 1.529 & 1.476 & 1.074 & 1.063 & 0.17 & 0.16 & 0.21 \\
\hline $6-1$ & Hwangnyongsa Temple site & $35^{\circ} 50^{\prime} 11^{\prime \prime}$ & $129^{\circ} 14^{\prime} 2^{\prime \prime}$ & 57 & 26.0 & 494 & $\mathrm{C}$ & 0.263 & 0.189 & 1.32 & 1.35 & 1.342 & 1.314 & 1.075 & 1.063 & 0.20 & 0.19 & 0.22 \\
\hline $6-2$ & $\begin{array}{l}\text { Stone pagoda of } \\
\text { Bunhwangsa Temple }\end{array}$ & $35^{\circ} 50^{\prime} 27^{\prime \prime}$ & $129^{\circ} 14^{\prime} 2^{\prime \prime}$ & 60 & 18.0 & 533 & $\mathrm{C}$ & 0.258 & 0.177 & 1.29 & 1.26 & 1.335 & 1.317 & 1.058 & 1.050 & 0.16 & 0.15 & 0.17 \\
\hline $6-4$ & $\begin{array}{l}\text { Myeonghwalsanseong } \\
\text { Fortress }\end{array}$ & $35^{\circ} 30^{\prime} 37^{\prime \prime}$ & $129^{\circ} 15^{\prime} 44^{\prime \prime}$ & 92 & 16.0 & 357 & $\mathrm{D}$ & 0.274 & 0.198 & 1.37 & 1.41 & 1.680 & 1.837 & 1.445 & 1.364 & 0.38 & 0.34 & 0.26 \\
\hline $8-0$ & $\begin{array}{l}\text { Yangdong Village of } \\
\text { Wolseong }\end{array}$ & $36^{\circ} 0^{\prime} 1^{\prime \prime}$ & $129^{\circ} 15^{\prime} 15^{\prime \prime}$ & 17 & 29.2 & 282 & $\mathrm{D}$ & 0.293 & 0.235 & 1.47 & 1.68 & 1.753 & 1.947 & 1.552 & 1.506 & 0.45 & 0.40 & 0.42 \\
\hline $8-1$ & Gwangajeong & $35^{\circ} 59^{\prime} 59^{\prime \prime}$ & $129^{\circ} 15^{\prime} 7^{\prime \prime}$ & 28 & 1.8 & 1437 & B & 0.205 & 0.144 & 1.03 & 1.03 & 1.003 & 1.003 & 1.000 & 1.000 & 0.04 & 0.04 & 0.04 \\
\hline $8-2$ & Hyangdan & $36^{\circ} 0^{\prime} 0^{\prime \prime}$ & $129^{\circ} 15^{\prime} 10^{\prime \prime}$ & 28 & 3.0 & 1223 & B & 0.208 & 0.145 & 1.04 & 1.04 & 1.006 & 1.006 & 1.001 & 1.001 & 0.05 & 0.05 & 0.05 \\
\hline $7-1$ & Mangdeoksa Temple site & $35^{\circ} 48^{\prime} 59^{\prime \prime}$ & $129^{\circ} 14^{\prime} 37^{\prime \prime}$ & 49 & 30.0 & 346 & $\mathrm{D}$ & 0.331 & 0.249 & 1.66 & 1.78 & 1.750 & 1.783 & 1.284 & 1.246 & 0.32 & 0.30 & 0.35 \\
\hline $7-2$ & $\begin{array}{l}\text { Flagpole support of in } \\
\text { Mangdeoksa Temple site }\end{array}$ & $35^{\circ} 48^{\prime} 57^{\prime \prime}$ & $129^{\circ} 14^{\prime} 40^{\prime \prime}$ & 48 & 30.0 & 290 & $\mathrm{D}$ & 0.330 & 0.254 & 1.65 & 1.81 & 1.898 & 2.092 & 1.577 & 1.532 & 0.44 & 0.39 & 0.41 \\
\hline $9-1$ & $\begin{array}{l}\text { Monument of King Tae- } \\
\text { jongmuyeol of Silla Period }\end{array}$ & $35^{\circ} 49^{\prime} 30^{\prime \prime}$ & $129^{\circ} 11^{\prime} 11^{\prime \prime}$ & 49 & 31.2 & 385 & C & 0.270 & 0.196 & 1.35 & 1.40 & 1.651 & 1.654 & 1.300 & 1.241 & 0.34 & 0.31 & 0.32 \\
\hline $4-4$ & $\begin{array}{l}\text { Three storied stone pagoda } \\
\text { of Goseonsa Temple } \\
\text { site, Gyeongju National } \\
\text { Museum }\end{array}$ & $35^{\circ} 49^{\prime} 46^{\prime \prime}$ & $129^{\circ} 13^{\prime} 46^{\prime \prime}$ & 56 & 32.0 & 432 & $\mathrm{C}$ & 0.323 & 0.235 & 1.62 & 1.68 & 1.804 & 1.771 & 1.216 & 1.178 & 0.27 & 0.25 & 0.29 \\
\hline $6-3$ & $\begin{array}{l}\text { Three storied stone pagoda } \\
\text { in Guhwang-dong }\end{array}$ & $35^{\circ} 49^{\prime} 54^{\prime \prime}$ & $129^{\circ} 14^{\prime} 33^{\prime \prime}$ & 71 & 10.0 & 563 & $\mathrm{C}$ & 0.266 & 0.193 & 1.33 & 1.38 & 1.318 & 1.284 & 1.041 & 1.034 & 0.13 & 0.12 & 0.11 \\
\hline $10-1$ & $\begin{array}{l}\text { Five storied stone pagoda in } \\
\text { Nawon-ri, Wolseong }\end{array}$ & $35^{\circ} 53^{\prime} 36^{\prime \prime}$ & $129^{\circ} 12^{\prime} 45^{\prime \prime}$ & 47 & 3.1 & 772 & B & 0.250 & 0.173 & 1.25 & 1.24 & 1.041 & 1.040 & 1.005 & 1.005 & 0.04 & 0.04 & 0.06 \\
\hline $11-1$ & $\begin{array}{l}\text { Thirteen storied stone } \\
\text { pagoda of Jeonghyesa } \\
\text { Temple site }\end{array}$ & $36^{\circ} 1^{\prime} 7^{\prime \prime}$ & $129^{\circ} 9^{\prime} 27^{\prime \prime}$ & 96 & 11.8 & 741 & C & 0.287 & 0.195 & 1.44 & 1.39 & 1.200 & 1.165 & 1.020 & 1.017 & 0.11 & 0.10 & 0.12 \\
\hline \multirow[t]{5}{*}{$12-1$} & $\begin{array}{l}\text { Three storied stone pagoda } \\
\text { of Gameunsa Temple site }\end{array}$ & $35^{\circ} 44^{\prime} 52^{\prime \prime}$ & $129^{\circ} 28^{\prime} 41^{\prime \prime}$ & 19 & 24.8 & 353 & $\mathrm{D}$ & 0.275 & 0.215 & 1.38 & 1.54 & 1.817 & 1.950 & 1.504 & 1.408 & 0.39 & 0.34 & 0.30 \\
\hline & Maximum Value & - & - & 251 & 32 & 1437 & - & 0.379 & 0.269 & 1.90 & 1.92 & 2.290 & 2.535 & 1.880 & 1.751 & 0.45 & 0.40 & 0.42 \\
\hline & Minimum Value & - & - & 17 & 1.8 & 282 & - & 0.205 & 0.144 & 1.03 & 1.03 & 1.003 & 1.003 & 1.000 & 1.000 & 0.04 & 0.04 & 0.04 \\
\hline & Mean Value & - & - & 86 & 18.8 & 532 & - & 0.292 & 0.214 & 1.46 & 1.53 & 1.551 & 1.589 & 1.204 & 1.178 & 0.23 & 0.21 & 0.22 \\
\hline & Standard Deviation & - & - & 76 & 8.9 & 250 & - & 0.04 & 0.035 & 0.20 & 0.25 & 0.289 & 0.341 & 0.212 & 0.180 & 0.12 & 0.10 & 0.10 \\
\hline
\end{tabular}




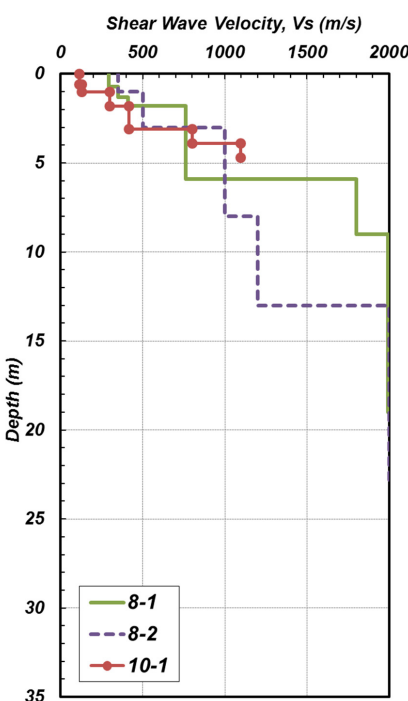

(a)

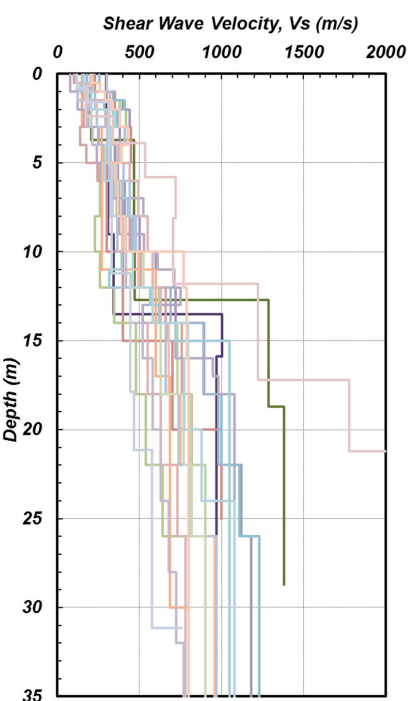

(b)

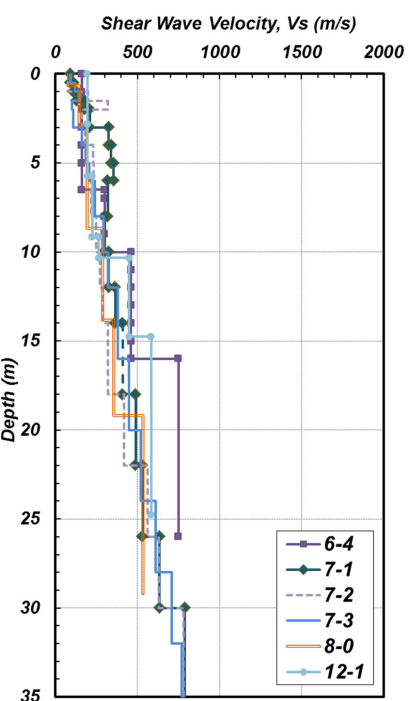

(c)

Fig. 2. Vs profiles around cultural heritage sites in Gyeongju; (a) site class B-3 sites, (b) site class C-21 sites, (c) site class D-6 sites.
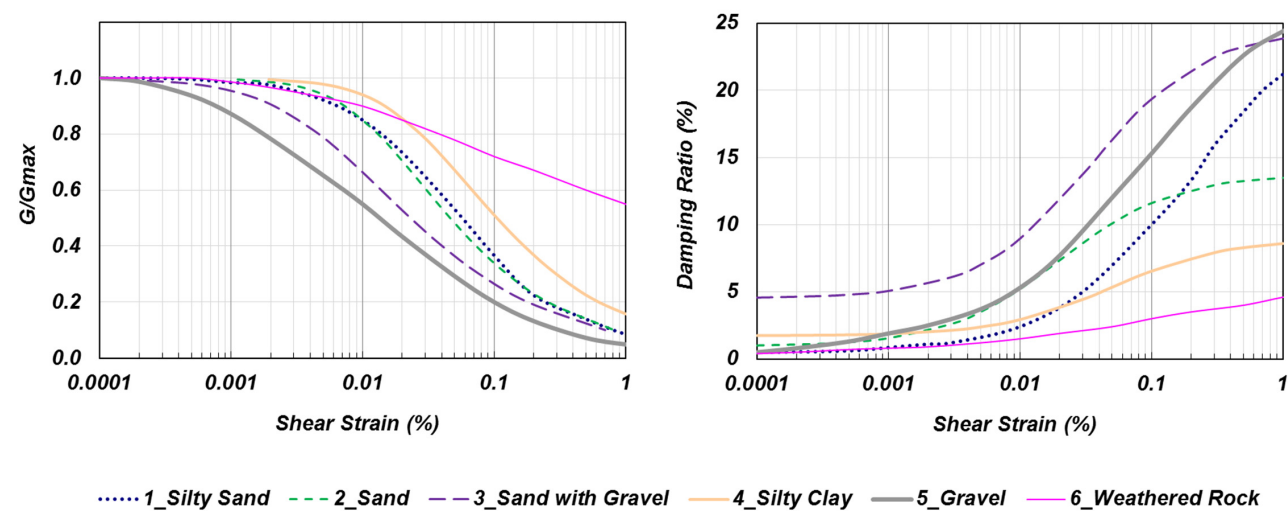

Fig. 3. Normalized shear modulus reduction and damping curves for site response analysis of Gyeongju.

The site amplification coefficient, which is the ratio of peak ground surface acceleration to peak bedrock acceleration, ranges between 1.03 and 1.92 . The mean value of the site amplification coefficient is 1.46 for the earthquake level of a $2400 \mathrm{yr}$ return period and 1.53 for the earthquake level of a $1000 \mathrm{yr}$ return period. Therefore, the current hazard map for the Gyeongju area has potential for site amplification of 1.5 times on average. It is necessary to reflect the potential amplification in the seismic hazard map in the future.

\subsection{Korean seismic design code and site-specific ground response analysis}

As the depth of bedrock in Korea is generally shallow, the natural site period of Korea is distributed in the short-period range of 0.1 to $0.5 \mathrm{~s}$. Since site effects are directly dependent on the local site effects, the use of site coefficients derived from earthquake records for quakes that occurred in different site conditions may lead to inaccurate estimation of the earthquake ground motion.

As aforementioned, the current seismic design code of Korea uses the site classification system and corresponding site coefficients given in the 1994 and 1997 NEHRP Provisions, despite the substantial differences in local geological conditions. Bedrocks are mostly located at shallower depth of less than $30 \mathrm{~m}$ in Korea. Vs30 can be affected by the stiffness of bedrock and may be overestimated if the bedrock depth is shallower than $30 \mathrm{~m}$.

Figure 5 shows the evaluated response spectra with a $5 \%$ damping ratio with response spectra of the Korean seismic design code for $22 S_{\mathrm{C}}$ sites of Gyeongju. In most cases, there are differences in the amplification coefficient and period range between the results of the site-specific response analysis and the current design code. The response 


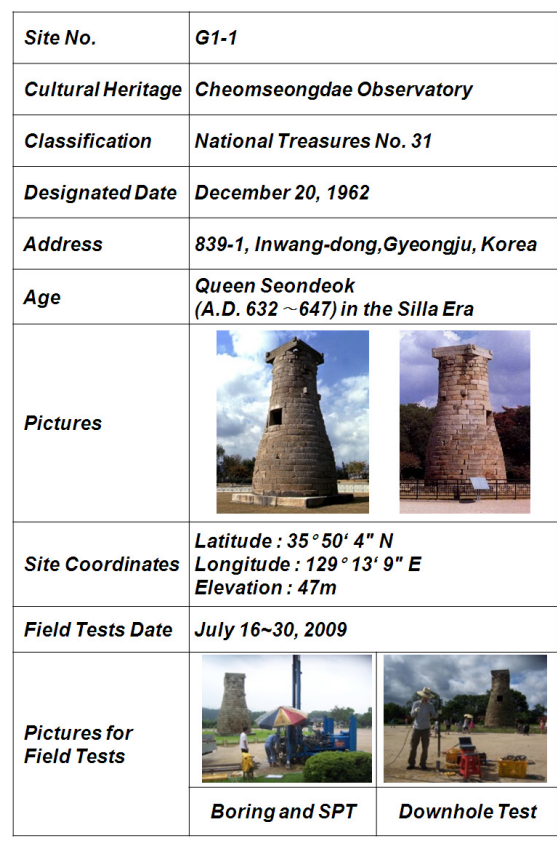

(a)

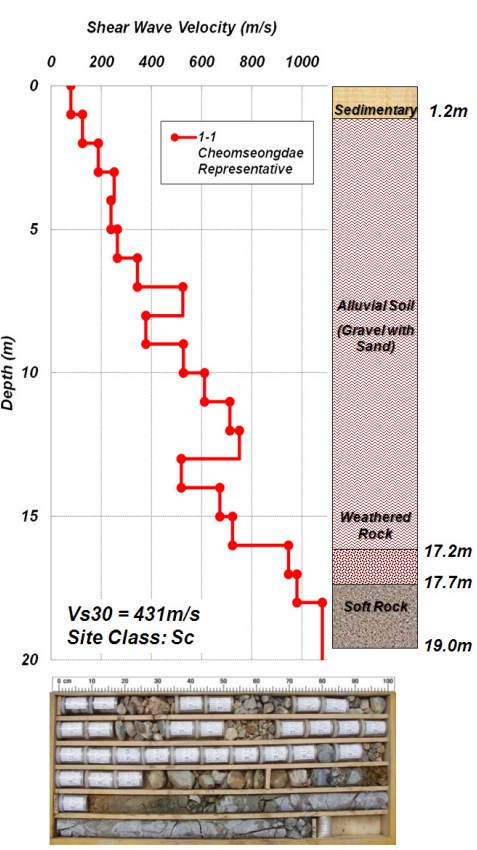

(b)

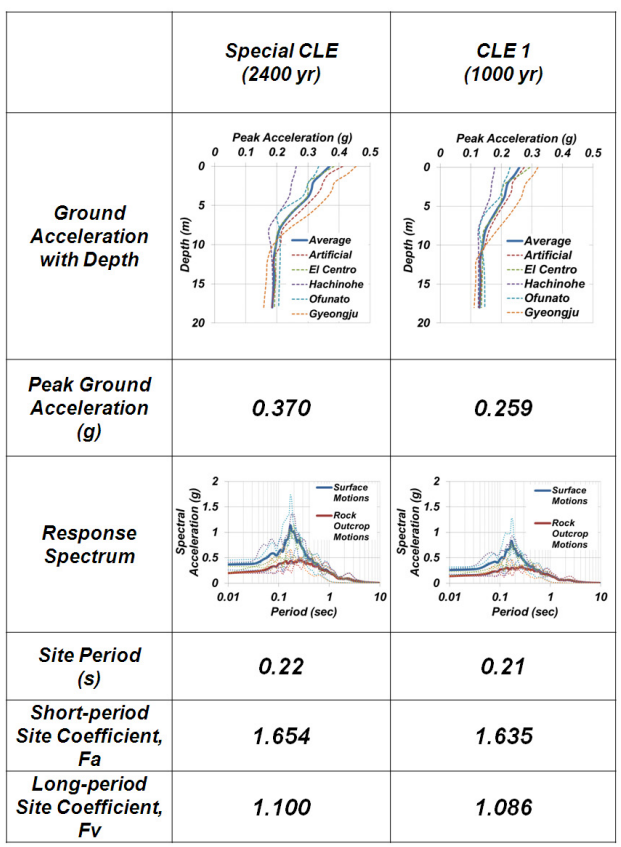

(c)

Fig. 4. The cultural heritage information and site-specific analysis results: (a) cultural heritage information and pictures; (b) in situ test results; (c) ground response analysis results

spectra for the Bulguksa Temple area, the Mount Namsan Belt, the Wolseong Belt, and the Tumuli Park Belt show larger resonance phenomena near site periods. In the case of the "Cheomseongdae observatory (Site No. 1-1)" in the Wolseong Belt, the evaluated response spectrum at a $\sim 0.15-0.25 \mathrm{~s}$ range is at most twice that of the coded response spectrum.

Site amplification coefficients were calculated for the thirty cultural heritage sites and the sixty sites of pre-existing data. Short-period site amplification coefficients (Fa) and long-period site amplification coefficients (Fv) were calculated using the ratio of response spectra (RRS) for the soil surface to the corresponding rock outcrop in a period range of 0.1 to $0.5 \mathrm{~s}$ and 0.4 to $2.0 \mathrm{~s}$, respectively (Kim and Yoon, 2005). Figure 6 shows the site amplification coefficients and corresponding site classification for the earthquake level of a $1000 \mathrm{yr}$ return period. Fa and $\mathrm{Fv}$ obtained from site response analyses considering geologic conditions differ significantly from the current Korean seismic design code. The Fa values were larger than those of the current Korean seismic design code, whereas the $\mathrm{Fv}$ values were smaller than those of the code in most cases. The evaluated and coded coefficients show extremely opposing values. The distribution of coded $\mathrm{Fv}$ values is similar to that of the evaluated Fa values, and the distribution of coded Fa values is similar to that of the evaluated $\mathrm{Fv}$ values. These results also show the necessity of a site-specific response analysis.

\section{GIS based seismic microzonation}

The seismic geotechnical information determined by a site response analysis was interpreted using a GIS tool. In order to assess the seismic vulnerability, the spatial data were collected to synthetically assess the earthquake hazard in Gyeongju historic areas. GIS based microzonation for seismic risk is becoming more common and more essential (Cid et al., 2001; Kim et al., 2002; Sun et al., 2005; Tyagunov et al., 2006; Glatron and Beck, 2008; Salamon et al., 2010). Seismic microzonation, which is a city scale hazards distribution mapping based on a geotechnical information system, made a reliable estimation of spatial geotechnical data for the Gyeongju historic areas. This system incorporates a geostatistical kriging interpolation technique, which can be adopted for reliable prediction of geotechnical data values. Kriging is considered to be the best linear unbiased estimate and optimal interpolation method for geological and geotechnical predictions in space, because it is a linear combination of weighted sample values that have minimum variance (Oliver and Webster, 1990).

The study area of interest for the GIS based seismic microzonation is a $7 \mathrm{~km}$ by $7 \mathrm{~km}$ area encompassing the city of Gyeongju. Sixty pre-existing site investigation datasets and twenty-one in situ test datasets for cultural heritage sites (including Fig. 2) were collected from the microzonation area.

A two-dimensional numerical topographical map, threedimensional digital elevation map, and standard geographical 

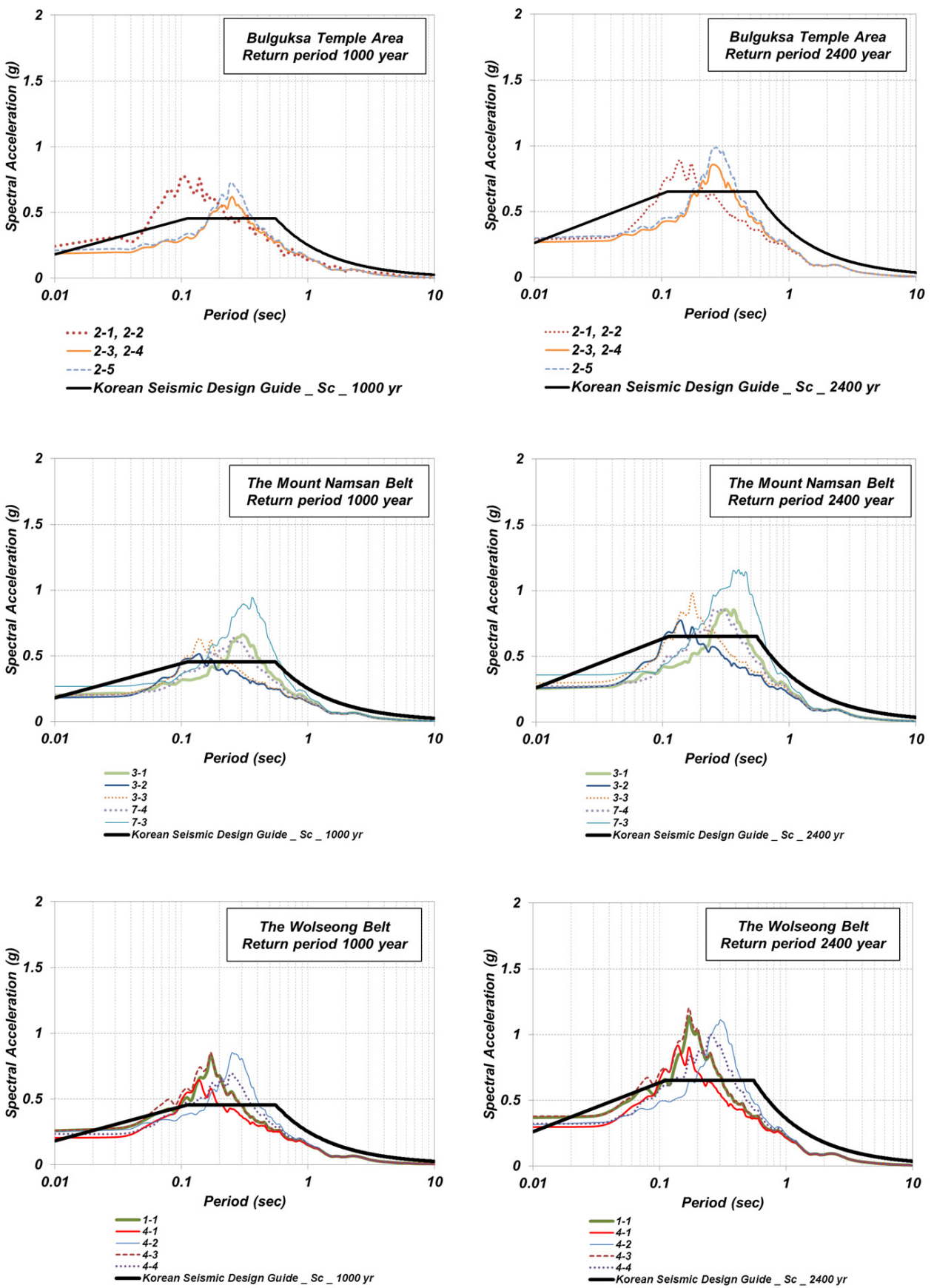

Fig. 5a. Comparison of response spectra between site-specific ground response analysis and Korean seismic design code.

information map were used to construct the geotechnical information system. First, a three-dimensional digital elevation map (3-D DEM) was constructed through the elevation information of the two-dimensional numerical topographical map and ASCII digital elevation values. The 3-D DEM was interpolated by the triangulated irregular network (TIN) in the MATLAB Mapping Toolbox (The MathWorks Inc., USA). Second, geostatistical kriging interpolation was performed for the geotechnical data. Next, the kriging results, standard geographical information map, and coordinate system were combined on the 3-D DEM. Figure 7 shows the construction procedure of the GIS based seismic microzonation system.

Each geotechnical information system is shown in Figs. 8 and 9. The seismic information systems for the bedrock depth, natural site period, peak ground acceleration, and short-period site amplification coefficients are interrelated 

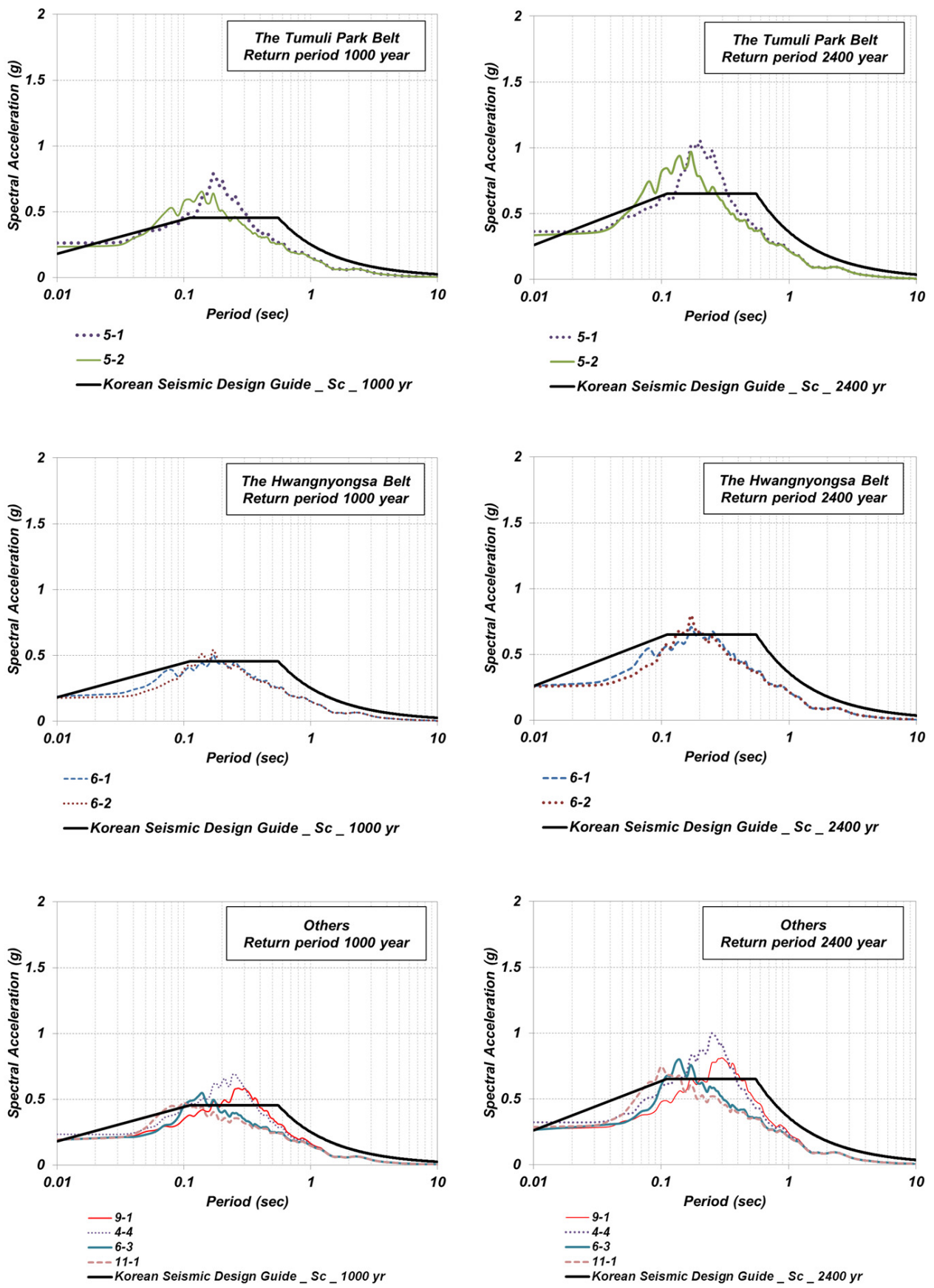

Fig. 5b. Continued.

and can be considered as reasonable results. The southeast area of Gyeongju has relatively deep bedrock, relatively high potential of site amplification and relatively large site period value.

Through the geotechnical information system for the site period of historic areas, presented in Fig. 8b, the correlation between the site period and the natural period of the architectural features can be shown and explained. Typically, the site period of the Cheomseongdae ground in the Wolseong Belt was calculated as $\sim 0.21-0.23 \mathrm{~s}$, as shown in Fig. 4. The natural period of Cheomseongdae was established as $4.52 \mathrm{~Hz}$ in the north-south direction and $4.59 \mathrm{~Hz}$ in the east-west direction through previous study (Shon and Kim, 2004). This illustrates that the ground near Cheomseongdae has high potential to suffer from site amplification nearby as well as resonance with the Cheomseongdae structure itself. 


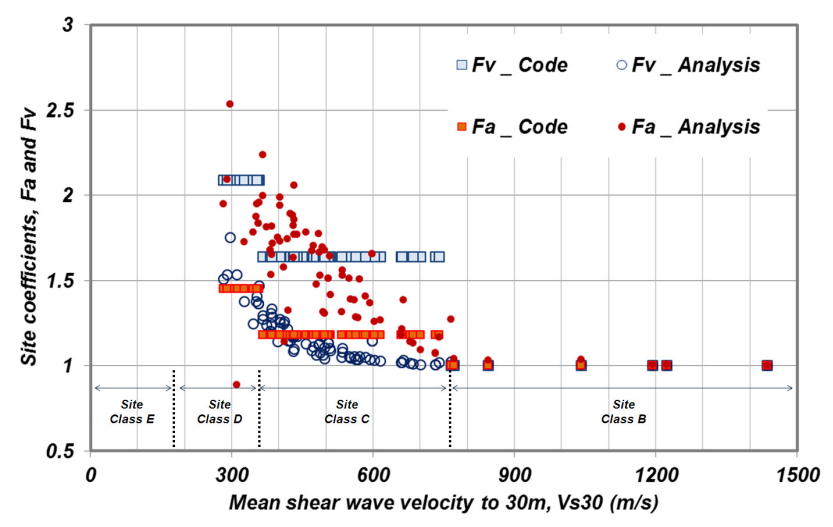

Fig. 6. Site amplification coefficients and corresponding site classification based on the Vs30 for the earthquake level of $1000 \mathrm{yr}$ return period.

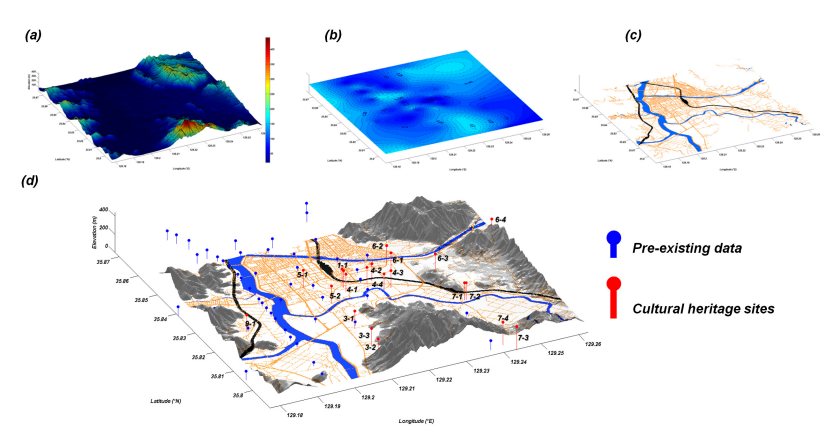

Fig. 7. The procedure of seismic microzonation: (a) threedimensional digital elevation map by the triangulated irregular network; (b) kriging interpolation of geotechnical value; (c) standard geographical information map; (d) combination of digital maps.

The geotechnical information system for peak ground acceleration and site coefficients of historic areas (Fig. 8c and d) show that the areas of "Cheomseongdae observatory (Site No. 1-1)" and "Imhaejeon Hall site (Site No. 4-3)", the plain area from "Mangdeoksa Temple site (Site No. 7-1)", and the "three storied stone pagoda in Namsan-ri (Site No. 7-3)" have relatively high potential for site amplification. In other words, the plain area of Wolseong Belt (Figs. 1 and 9) and the southeast area of Gyeongju (Fig. 9) have strong possibility for site amplification during earthquakes.

The construction of a GIS based seismic microzonation system would provide spatial and visible information for seismic risk of cultural heritages and historic sites. This system can include very important information on the overall countermeasures against earthquake disasters of historic areas, such as Gyeongju. The data can be usefully employed for seismic risk assessment by sub-regional groups or by each architectural heritage.

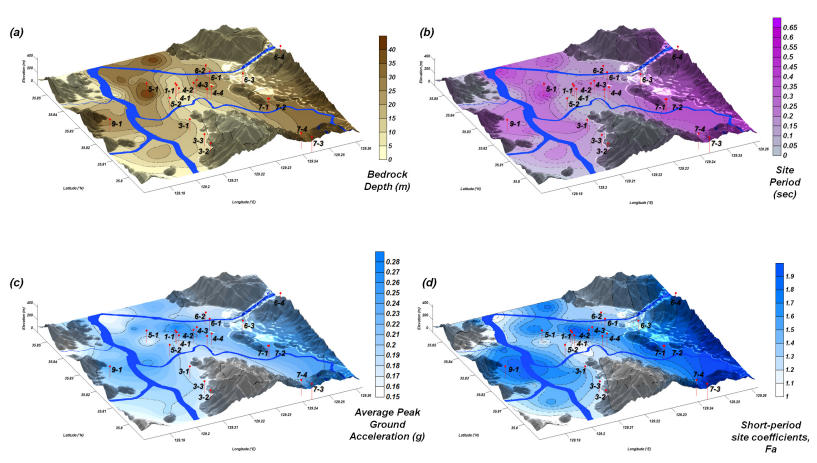

Fig. 8. GIS based geotechnical information system for the earthquake level of $1000 \mathrm{yr}$ return period: (a) the bedrock depth; (b) natural site period; (c) peak ground acceleration; (d) short-period site amplification coefficients, Fa.

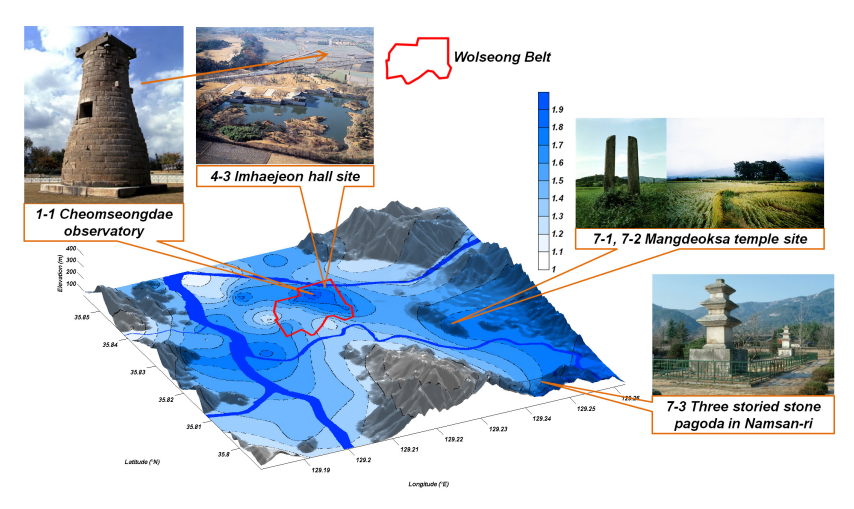

Fig. 9. GIS based geotechnical information system for peak ground surface acceleration for the earthquake level of $1000 \mathrm{yr}$ return period and the cultural heritage areas which have relatively high potentials for site amplification.

\section{Conclusions}

Gyeongju is the most important historic city in Korea, boasting a wealth of historic sites and a legacy of cultural heritage dating back more than a thousand years. The necessity of estimating the seismic risk of historic areas has been widely recognized. Thirty in situ test sites around cultural heritages and sixty pre-existing site investigation datasets were selected and a revaluation of the historical records of seismic damage in Gyeongju was performed. Site-specific ground response analyses based on the in situ site investigation of the subsurface ground were performed. The evaluation of seismic risk through GIS based microzonation for the historic area was then conducted.

The response spectra and site amplification coefficients were compared between site response analysis and current seismic design code, and it was thereupon found that the current hazard map for the Gyeongju area has potential for site amplification of 1.5 times on average. Furthermore, the plain area of the Wolseong Belt and the southeast area of 
Gyeongju have a strong possibility for site amplification during earthquakes.

Acknowledgements. This study, which forms a part of the project, has been achieved with the support of national R\&D project, which has been hosted by National Research Institute of Cultural Heritage of Cultural Heritage Administration. We express our gratitude to it.

Edited by: M. E. Contadakis

Reviewed by: A. De Santis and one anonymous referee

\section{References}

Aki, K.: Local site effects on weak and strong ground motion, edited by: F. Lund, New Horizons in Strong Motion: Seismic Studies and Engineering Practice, Tectonophysics, 218, 93-111, 1993.

BSSC: NEHRP Recommendation Provisions for Seismic Regulations for New Buildings and Other Structures: Part 1. Provisions, 1994 Ed., Building Seismic Safety Council, Washington, D.C., 1994.

BSSC: NEHRP Recommendation Provisions for Seismic Regulations for New Buildings and Other Structures: Part 1. Provisions, 1997 Ed., Building Seismic Safety Council, Washington, D.C., 1997.

Chavez-Garcia, F. J.: Site effects: From observation and modelling to accounting for them in building codes, in: Earthquake Geotechnical Engineering, edited by: Pitilakis, K. D., Springer, 53-72, 4th International Conference on Earthquake Geotechnical Engineering (4ICEGE), Thessaloniki, Greece, 2007.

Cid, J., Susagna, T., and Goula, X.: Seismic zonation of Barcelona based on numerical simulation of site effects, Pure Appl. Geophys., 158, 2559-2577, 2001.

Glatron, S. and Beck, E.: Evaluation of socio-spatial vulnerability of citydwellers and analysis of risk perception: industrial and seismic risks in Mulhouse, Nat. Hazards Earth Syst. Sci., 8, 10291040, doi:10.5194/nhess-8-1029-2008, 2008.

Kim, D. S. and Yoon, J. K.: Development of new site classification system for the regions of shallow bedrock in Korea, J. Earthquake Eng., 10, 331-358, 2005.

Kim, D. S., Chung, C. K., Sun, C. G., and Bang, E. S.: Site assessment and evaluation of spatial earthquake ground motion of Kyeongju, Soil Dynam. Earthquake Eng., 22, 371-387, 2002.
Kim, D. S., Park, H. J., Kim, J. T., Kim, N. R., and Bang, E. S.: Evaluation of spatial variations in soil stiffness using stress wave propagations, Proceedings of International Conference on Performance-Based Design in Earthquake Geotechnical Engineering (IS-Tokyo2009), 163-178, 15-18 June, Tsukuba, Japan, 2009.

Lee, S.-H., Sun, C.-G., Yoon, J.-K., and Kim, D.-S.: Development and Verification of a New Site Classification System and Site Coefficients for Regions of Shallow Bedrock in Korea, J. Earthquake Eng., 16, 795-819, 2012.

Ministry of Construction and Transportation, Korean Seismic Design Standard, 493 pp., 1997 (in Korean).

National Research Institute of Cultural Heritage (NRICH): Study on the evaluation method for flood and seismic risks of architectural heritage, 316 pp., 2009 (in Korean).

Oliver, M. A. and Webster, R.: Kriging: a method of interpolation for geographical information systems, Int. J. Geogr. Inform. Syst., 4, 313-332, 1990.

Park, H. C. and Kim, D. S.: Evaluation of the dispersive phase and group velocities using harmonic wavelet transform, NDT\&E International, 34, 457-467, 2001.

Pitilakis, K.: Site effects, in: Recent Advances in Earthquake Geotechnical Engineering and Microzonation, edited by: Ansal, A., Kluwer Academic Publishers, 139-197, 2004.

Salamon, A., Katz, O., and Crouvi, O.: Zones of required investigation for earthquake-related hazards in Jerusalem, Nat. Hazards, 53, 375-406, 2010.

Schnabel, P. B., Lysmer, J., and Seed, H. B.: SHAKE: a computer program for earthquake response analysis of horizontally layered sites, Report EERC 72-12, Earthquake Engineering Research Center, University of California, Berkeley, 1972.

Seed, H. B., Wong, R. T., Idriss, I. M., and Tokimatsu, K.: Moduli and Damping Factors for Dynamic Analyses of Cohesionless Soils, J. Geotech. Eng., 112, 1016-1032, 1986.

Shon, H. and Kim, S. B.: Studies on the characteristics of stone structures by shape reversal, geotechnical and dynamic structural engineerings, Proceedings of conference on Korean Society of Earth and Exploration Geophysicists, 25-48, 2004 (in Korean).

Sun, C. G., Kim, D. S., and Chung, C. K.: Geologic site conditions and site coefficients for estimating earthquake ground motions in the inland areas of Korea, Eng. Geol., 81, 446-469, 2005.

Tyagunov, S., Grünthal, G., Wahlström, R., Stempniewski, L., and Zschau, J.: Seismic risk mapping for Germany, Nat. Hazards Earth Syst. Sci., 6, 573-586, doi:10.5194/nhess-6-573-2006, 2006. 